\title{
Insight
}

ChINA \& WTO ReV. 2017:2; 407-410

http://dx.doi.org/10.14330/cwr.2017.3.2.10

pISSN 2383-8221 • elSSN 2384-4388

\section{China's THAAD Retaliation and the GATS Rules}

Sun Young $\mathrm{Oh}^{*}$

Professor at Soongsil University

The Terminal High Altitude Area Defense ("THAAD"), which is a US' antiballistic missile defense system, has been deployed to South Korea earlier in this year. The US and South Korea allegedly agreed to deploy THAAD as a defensive measure to prevent the North Korea's continuous nuclear weapon tests and ballistic missile launches.

However, China believes that these sophisticated and powerful THAAD radars could track China's missile systems, so that the US could hold a lead in any future conflicts with China. In the recent ASEAN Regional Forum, held in Manila, Chinese Foreign Minister Wang Yi expressed deep concern about South Korea's decision to proceed with the temporary deployment of additional THAAD. ${ }^{1}$ In response to deployment of THAAD, China has placed economic restrictions on Korea. Indeed, China blocked charter flights to South Korea without assigning any reasons whatsoever, and Chinese travel agencies stopped the sale of all travel packages to South Korea and even cancelled tours by K-pop stars. ${ }^{2}$ Chinese pressure also brought the boycott of South Korea's products and Lotte stores.

The Chinese trade retaliation, a travel ban in particular, results in billions of dollars in lost travel related revenue, and this travel service sector has been severely suffered. While trying to consult with China regarding its trade retaliation, South Korea has raised a formal complaint with the WTO's Council for Trade in Service and TBT Committee. ${ }^{3}$ However, China has denied that recent movements are related to the THAAD deployment and any official involvement was made.

In order to determine whether these Chinese retaliation actions could be covered under the WTO jurisprudence, first of all, there must be governmental 
involvement. In other words, these sanctions should be considered as 'government measures,' not just mere private voluntary actions. The major China's excuse is that there were no government orders or delegation, and thus, these actions are taking place unofficially. ${ }^{4}$ According to the GATS, the measures are defined as "any measure by a Member, whether in the form of law, regulation, rule, procedure, decision, administrative action, or any other form." In this case, there are significant circumstantial evidences to prove the Chinese government's involvement in trade retaliation. There were verbal instructions by the China National Tourism Administration ("CNTA") to suspend sales of tour tickets to South Korea on March 2, 2017. ${ }^{6}$ Furthermore, the CNTA also gave a written instruction to cancel group tours departing after March 15, and non-compliance of this order was subject to fines and travel agencies' licenses could be revoked. ${ }^{7}$

Once it is proven that these restrictive measures were carried out by the Chinese government, it is highly likely to rule that travel banning is inconsistent with Model 2 Commitment in GATS because it has breached the market access (Article XVI) and national treatment (Article XVII) rules. Indeed, China has promised to make full commitments in Mode 2, and it covers the supply of a service through consumption abroad in the territory of one Member to the service consumer of any other Member. In this case, the Chinese government restricts that a service consumer (i.e. Chinese citizens) moves into another Member's territory (i.e. South Korea) to obtain a service (travel), and thus, China hinders market access of travel services, and treats South Korea less favorable than others.

Moreover, China appears to violate national treatment obligation in Mode 3 Commitment under retailing services by boycotting Lotte stores, in particular. Mode 3 refers to commercial presence in the wholesale and retailing trade, and it covers the service provided by a locally-established affiliate, subsidiary, or representative office of a foreign owned (i.e. South Korea) within other Member's territory (i.e. China). According to the GATS, China is obliged to grant South Korean's suppliers treatment no less favorable than that extended to its own service suppliers unless otherwise indicated in the schedule. Again, it has to be clearly proven that this boycotting was ordered directly or indirectly by the Chinese government, not by Chinese citizens' voluntary actions.

China might want to invoke the security exception clause (Article XIV) to justify its measures. However, it is unlikely to be justified because deployment of 
THAAD was designed to protect against threats and attack from North Korea, not to attack China. In principle, exception clauses have been narrowly construed. It should be noted that both parties agreed to liberalize the travel agencies in KoreaChina FTA.

Since dispute resolution must start with consultation and as such adjudications must be the last resort. Therefore, both China and South Korea need to ease THAAD tensions amicably first.

\section{REFERENCES}

1. A. Panda, China Hits Back at South Korea's THAAD Deployment Following North Korea's Latest ICBM Test, Diplomat, Aug. 8, 2017, available at http://thediplomat.com/2017/08/ china-hits-back-at-south-koreas-thaad-deployment-following-north-koreas-latest-icbm-test. See also E. Rauhala, China's anger over U.S. antimissile system poses challenge to Trump, WASH. Post, Mar. 7, 2017, available at https://www.washingtonpost.com/world/asia_pacific/ china-warns-of-consequences-over-deployment-of-us-anti-missile-system/2017/03/07/ dd5ca494-0319-11e7-a391-651727e77fc0_story.html?tid=a_inl\&utm_term=.88e7cbcca203 (all last visited on Aug. 9, 2017).

2. A. Diaz \& Shuai Zhang, Angered by U.S. anti-missile system, China takes economic revenge, CBS News, April 7, 2017, available at http://www.cbsnews.com/news/china-retaliates-southkorea-us-thaad-missile-defense-lotte-and-k-pop (last visited on Aug. 9, 2017).

3. See South Korea complains to WTO over China response to missile system, REUTERS, Mar. 20, 2017, available at http://www.reuters.com/article/us-southkorea-china-thaadidUSKBN16R03D (last visited on Aug. 9, 2017).

4. See South Korea considering WTO claim to address China's THAAD retaliation, HANKYOREH DAILY, Mar. 8, 2017, available at http://english.hani.co.kr/arti/english_edition/e national/785621.html (last visited on Aug. 9, 2017).

5. GATS art. XXVIII (a)

6. See China bans trip sales to Korea, YonHAP News, Mar. 2, 2017, available at http://english. yonhapnews.co.kr/business/2017/03/02/0501000000AEN20170302012700320.html (last visited on Aug. 9, 2017).

7. See China bans tour groups to South Korea as defence spat worsens, FIn. TIMES, Mar. 3, 2017, available at https://www.ft.com/content/9fc4b1b4-ffb1-11e6-96f8-3700c5664d30 (last visited on Aug. 9, 2017). 